\title{
The Effect of Transitional Organic Production Practices on Soilborne Pests of Tomato in a Simulated Microplot Study
}

\author{
Dan O. Chellemi, Erin N. Rosskopf, and Nancy Kokalis-Burelle
}

United States Department of Agriculture-Agricultural Research Service, U.S. Horticulture Research Laboratory, Fort Pierce, FL 34945. Accepted for publication 27 February 2013.

\begin{abstract}
Chellemi, D. O., Rosskopf, E. N., and Kokalis-Burelle, N. 2013. The effect of transitional organic production practices on soilborne pests of tomato. Phytopathology 103:792-801.

The perceived risk of pest resurgence upon transition from conventional to organic-based farming systems remains a critical obstacle to expanding organic vegetable production, particularly where chemical fumigants have provided soilborne pest and disease control. Microplots were used to study the effects of soil amendments and cropping sequences applied over a 2-year transitional period from conventional to organic tomato (Solanum lycopersicum) cultivation on the incidence of bacterial wilt caused by Ralstonia solanacearum, purple nutsedge (Cyperus rotundus) reproduction, root galling by Meloidogyne incognita, and soil nematode populations. A continuation of tomato monoculture

frumentacea). The benefits of disease control from a crop rotation extended into to a second season of organic tomato cultivation season, where bacterial wilt declined from $40 \%$ in microplots with a tomato monoculture to $17 \%$ in plots with a crop rotation sequence. Combining applications of urban plant debris with a continued tomato monoculture increased the incidence of bacterial wilt to $60 \%$. During the transition period, tomato plants following a cover crop regime also had significantly lower levels of root galling from root-knot nematode infection compared with plants in the continuous tomato monoculture. Nutsedge tuber production was significantly increased in plots amended with broiler litter but not urban plant debris. Compared with a continuous monoculture, the results illustrate the importance of a systems-based approach to implementing transitional organic practices that is cognizant of their interactive effects on resident soilborne disease, weed, and pest complexes.
\end{abstract} during the transitional period resulted in a disease incidence of $33 \%$, as compared with $9 \%$ in microplots that were rotated with sunn hemp (Crotalaria juncea) and Japanese millet (Echinochloa crusgalli var.
Additional keywords: organic agriculture, soil fumigants.
Certified organic crop production has increased dramatically over the last decade to meet the demands of a growing global market. In the United States, retail sales of organic foods increased from \$3.6 billion in 2000 to $\$ 21.1$ billion in 2008, with a corresponding increase of the market share of total U.S. food sales from 1.2 to $4.0 \%$ (24). Availability of certified organic farmland has not kept pace with the increasing market demand. This is particularly evident for vegetable production where, despite an increase in certified organic acreage from 62,000 acres in 2000 to 169,000 in 2008 , periodic shortages of organic vegetable products occur (24). A significant portion of the U.S. winter supply of fresh market tomato (Solanum lycopersicum L.) is grown in the ecologically sensitive Florida Everglades Watershed (FEW). Creating new organic farms in the FEW is difficult due to competition with urban development, wetlands conservation, and native habitat restoration. Converting existing conventional vegetable farms in the FEW to certified organic farms is a more feasible approach for meeting the growing market demand.

Since the 1960s, fresh market tomato producers in the 25,000 $\mathrm{km}^{2}$ FEW have relied exclusively upon the single-tactic approach of soil fumigation with mixtures of methyl bromide and chloropicrin for controlling soilborne diseases and pests $(26,58)$. Alternative fumigants were developed as "drop-in" replacements $(15,29,37)$ after a phase-out of production and importation of

Corresponding author. D. O. Chellemi, E-mail address: dan.chellemi@ars.usda.gov

http://dx.doi.org/10.1094/PHYTO-09-12-0243-R

This article is in the public domain and not copyrightable. It may be freely reprinted with customary crediting of the source. The American Phytopathological Society, 2013. methyl bromide was implemented due to its destructive effects on stratospheric ozone (25). The use of chemical fumigants for soil disinfestation is considered critical due to intense pressure from soilborne pests and diseases and, without them, winter production of Florida tomato was projected to decline by $60 \%$, resulting in direct economic losses exceeding $\$ 360$ million (48). With the best available fumigant alternatives, losses to tomato and strawberry production have been estimated at 39 to $42 \%$ of net revenue, respectively (53). Most agricultural soils in the FEW are poorlydrained Alfisols and Spodosols that overlay a perched water table $(27,41)$, facilitating surface water infiltration of nutrients and pesticides during periods of abundant rainfall. The soils are composed primarily of sand, have little organic matter, and have low cation-exchange capacities, necessitating the addition of large quantities of organic material during the organic transitional period (14).

Even though organic and reduced-input systems can mitigate the impact of root diseases when compared with conventional systems (54), many farmers are reluctant to switch to organic production due to the risk of pest resurgence following the required transitional period. In some instances, their concerns of pest resurgence are warranted. A review of organic amendment applications by Bonanomi et al. (8) identified significant disease suppression occurring in $45 \%$ of 2,423 experimental case studies while disease resurgence occurred in $20 \%$ of the case studies. In the FEW, resurgence of soilborne diseases and pests limits the capability of conventional tomato farms to produce multiple crops, despite the use of soil fumigants $(28,35)$. Identifying organic transitional practices that mitigate or exacerbate damage from soilborne diseases and pests would facilitate risk assessment of pest resurgence following conversion from conventional to organic production. The objective of this study was to ascertain 
the effect of a 2-year transitional period of organic amendments that consisted of urban plant debris (UPD) and broiler litter (BL) applied under a continuous tomato monoculture or an alternative crop rotation on a soilborne pest complex consisting of bacterial wilt (Ralstonia solanacearum Smith), root-knot nematode (Meloidogyne incognita Kofoid \& White), and purple nutsedge (Cyperus rotundus L.).

\section{MATERIALS AND METHODS}

To simulate transition from conventional tomato production employing management practices conducive to the build-up of soilborne pests and diseases, microplots were preconditioned for 2 years using conventional practices, including soil fumigation. The selection of organic amendments and cropping sequences was based upon the results of prior studies investigating the biological and crop production impacts of diverse land management practices, including organic production, on tomato crop health $(14,18)$. Following the transition period, pest resurgence on tomato was evaluated in all microplots for multiple tomato crops.

Preconditioning microplots to simulate conventional tomato production in the FEW. Experiments were conducted in microplots located at the United States Department of Agriculture-Agricultural Research Service, U.S. Horticultural Research Laboratory (USHRL), Picos Road Farm in Ft. Pierce, FL. Ninety microplots were constructed from $30-$ by-30-cm ceramic flues measuring $0.9 \mathrm{~m}$ in length. The flues were open at both ends and buried in the ground, with a $5-\mathrm{cm}$ lip remaining above the ground. Soil type was an Oldsmar fine sand, typical for depressional flatwood areas of the FEW (56) and commonly used for citrus, sugarcane, and vegetable production $(27,41)$. Soil bulk density was $1.45 \mathrm{~g} \mathrm{~cm}^{-3}$, soil pH was 6.3 , organic carbon content was $12 \mathrm{~g} \mathrm{~kg}^{-1}$ of soil, and soil texture was $98 \%$ sand and $2 \%$ clay. The soil was naturally infested with $R$. solanacearum.

Microplots were fumigated on 30 March 2006 with a 67:33 formulation of methyl bromide:chloropicrin at $240 \mathrm{~kg} \mathrm{ha}^{-1}$ to a depth of $30 \mathrm{~cm}$ and covered with metalized plastic film. Tomato seedlings ('Tiny Tim') were transplanted into plots and weekly applications of a synthetic water-soluble fertilizer $\left(\mathrm{N}-\mathrm{P}_{2} \mathrm{O}_{5}-\mathrm{K}_{2} \mathrm{O}\right.$ at 200 ppm, plus minor elements) (J. R. Peters, Inc., Allentown, PA) were made during the crop. Plants in the microplots were periodically replaced with new seedlings to create a continuous tomato monoculture. A timeline of activities performed in the microplots is presented in Figure 1.

In an attempt to promote Fusarium wilt, microplots were inoculated with single-spore isolates of Fusarium oxysporum f. sp. lycopersici W. C. Snyder \& H. N. Hansen race 3 during the transplanting of tomato seedlings on 6 October 2006 and 3 March 2007 using an infested wheat seed technique. Fungal cultures were grown on potato dextrose agar (PDA) for 6 days in the laboratory under $12 \mathrm{~h}$ of fluorescent light. One-liter flasks containing $200 \mathrm{ml}$ of deionized water and $200 \mathrm{~g}$ of wheat seed were inoculated with $101-\mathrm{mm}$ plugs taken from the edge of the colonies. Flasks containing seed and water were autoclaved twice over a 2-day period prior to inoculation. The infested wheat seed was grown for 27 days in the laboratory under $12 \mathrm{~h}$ of fluorescent light; then, $40 \mathrm{~g}$ were mixed into each microplot prior to transplanting.

Microplots were inoculated with $M$. incognita using nematodes extracted from pure cultures of $M$. incognita maintained in the greenhouse on tomato ('Rutgers'). Root-knot nematode species identifications were confirmed based on esterase phenotype (PhastSystem; GE Healthcare, Piscataway, NJ) before inoculation of microplots. $M$. incognita eggs were extracted from tomato roots using a modified $\mathrm{NaOCl}$ method (32). The final concentration of eggs, collected on $25-\mu \mathrm{m}$-pore sieves, was adjusted to $1,000 \mathrm{eggs} / \mathrm{ml}$. Microplots were inoculated with nematode eggs by pipetting five $1-\mathrm{ml}$ aliquots of egg suspension into $2-\mathrm{cm}$-deep impressions in the soil in the center planting zone of each plot. Inoculation sites were covered lightly with soil, and plots were lightly watered.

Microplots were infested with $C$. rotundus using field-collected purple nutsedge tubers of $\approx 1$ to $1.5 \mathrm{~cm}$ in diameter. Tubers were trimmed and washed and four viable (30) tubers were planted into each of the 90 microplots on 11 October 2006. Tubers were planted $\approx 3 \mathrm{~cm}$ from the wall of the microplot and $4.5 \mathrm{~cm}$ deep. Tubers emerged in all plots within 7 days of planting.

Transitional organic production practices. On 22 April 2008, transitional organic practices were initiated. A 3-by-3-by-2 factorial design was established using three rates of UPD $(0,30$, and $60 \mathrm{~g} \mathrm{~kg}^{-1}$ of soil), three rates of $\operatorname{BL}\left(0,10\right.$, and $20 \mathrm{~g} \mathrm{~kg}^{-1}$ of soil), and two cropping sequences (a continuation of conventional tomato monoculture and an alternative crop rotation described below). Treatments were arranged in a randomized complete block design with five replications. UPD and BL were added in April 2008, 2009, and 2010 by removing soil to a depth of $15 \mathrm{~cm}$ $\left(13,935 \mathrm{~cm}^{3}\right.$ of soil), mixing with the appropriate rates of UPD and $\mathrm{BL}$ in a portable cement mixer, and then placing amended soil back into the microplots. UPD was obtained from the Volusia County Solid Waste Authority (Daytona Beach, FL) and was partially composted and tub ground through a 2.5-cm mesh screen. BL was obtained from broiler production houses (Boyd Bros., Live Oak, FL) as a mixture of pine shavings (percentage unknown) and manure that was dry stock, aged 6 to 12 weeks in static row piles, and having an ash content below 25\%. Soil amendment rates and their relative contribution of nitrogen, ammonia, phosphorus, and potassium are listed in Table 1. In microplots that did not receive UPD or BL ( 0 application rates of each), a conventional synthetic fertilizer (6-6-6; Diamond $\mathrm{R}$ Fertilizer, Fort Pierce, FL) was added using the application rates shown in Table 1. Microplots were solarized after adding the soil amendments by applying clear plastic to the soil surface. This same sequence of activities was performed in previous studies $(14,18)$ and typically practiced by organic growers in the FEW. In 2008, no solarization was applied to the conventional microplots (microplots not receiving an application of BL or UPD). Hourly soil temperatures were monitored at depths of 5,15 , and $25 \mathrm{~cm}$ using thermocouple sensors placed in the center of microplots. An electronic data logger automatically processed and recorded analog signals from the sensors (Omnidata International, Logan, UT). Solarization dates, thermal accumulation, and comparison with soil temperatures under nonsolarized (bare) soil are provided in Table 2. Microplots were planted to tomato (Tiny Tim) or a crop rotation consisting of sunn hemp (Crotalaria juncea L.) grown during the summer and Japanese millet (Echinochloa crusgalli var. frumentacea L.) grown in the winter months.

Evaluating pest resurgence. After terminating the soil solarization period in 2010, consecutive tomato crops (fall 2010 and spring 2011) were initiated in all microplots, including those previously subjected to the alternative crop rotation. On 12 July 2010, one tomato seedling ('Florida 91') was transplanted into each microplot. Microplots were managed under organic production methods, except for conventional microplots that did not receive an application of BL or UPD. Soil fertility in conventional plots was provided by a synthetically derived blend of fertilizer. Supplemental applications of a liquid soluble blend of fish oil (5-1-1 of $\mathrm{N}-\mathrm{P}_{2} \mathrm{O}_{5}-\mathrm{K}_{2} \mathrm{O}$ ), with $\mathrm{N}$ at 250 ppm, were made on a weekly basis in all plots, except plots that did not contain UPD or $\mathrm{BL}$, which were fertilized with a synthetic liquid fertilizer (9-3-6 of $\mathrm{N}-\mathrm{P}_{2} \mathrm{O}_{5}-\mathrm{K}_{2} \mathrm{O}$ ), with $\mathrm{N}$ at $250 \mathrm{ppm}$. The crop was terminated on 22 October 2010. A second tomato crop ('Security') was transplanted on 22 March 2011. The second tomato crop was cultivated through the spring 2011 season using methods identical to the fall 2010 crop. The spring 2011 crop was terminated on 20 June 2011. 
Disease incidence was assessed weekly. Koch's postulates were performed to verify visual diagnosis on a representative number of plants. Crown tissue with symptomatic necrosis of phloem tissue (Fusarium wilt) or bacterial streaming (bacterial wilt) were washed in tap water, cut into 1-cm sections, and surface sterilized with $\mathrm{NaOCl}$ at $1,000 \mu \mathrm{g}$ liter $^{-1}$ for $90 \mathrm{~s}$ followed by a 90 -s rinse with sterile deionized water. For Fusarium wilt, crowns were blotted dry on sterile paper towels and plated onto an agar medium containing $39 \mathrm{~g}$ of Difco PDA, $0.25 \mathrm{~g}$ of ampicillin, 0.01 $\mathrm{g}$ of rifampicin, and $0.1 \mathrm{ml}$ of tergitol per liter of $\mathrm{H}_{2} \mathrm{O}$. Plates were incubated in the dark at $27^{\circ} \mathrm{C}$ with $8 \mathrm{~h}$ per day of fluorescent light. Fungal colonies identified as $F$. oxysporum were tested for pathogenicity on tomato seedlings ('Bonny Best'; Totally Tomatoes, Augusta, GA) using a root dip method described by Bao et al. (5). For bacterial wilt, crown tissue was ground in a mortar and pestle and streaked onto nutrient agar. Colonies identified as $R$. solanacearum were tested for pathogenicity on tomato seedlings by inoculating stems with a hypodermic needle dipped into individual suspect colonies.
Assessments of soil nematode populations were made at the termination of the fall 2010 and spring 2011 crop by removing two soil cores in each plot using a $1.75-\mathrm{cm}$ internal diameter soil probe. A $100-\mathrm{cm}^{3}$ subsample was used for nematode extraction. Nematodes were extracted from both soil and roots using the Baermann funnel technique. In addition to root-knot nematode J2, other parasitic nematodes and microbivorous (nonparasitic) nematodes were counted for both soil and roots. Other parasitic nematodes were primarily spiral nematodes (Helicotylenchus spp.). Damage to root systems by $M$. incognita was determined by physically removing roots and visually rating the severity of root galling using a scale of 0 to 10 , with 0 representing no galls and 10 representing severe $(100 \%)$ galling (10).

At the termination of the crop in June 2011, the percent surface area covered by purple nutsedge shoots was visually estimated. The number of nutsedge tubers per microplot was determined by removing the top $15 \mathrm{~cm}$ of soil from each microplot at each soil amendment event and sifting the soil with a $1-\mathrm{cm}^{2}$ sieve to collect the tubers. Nonviable tubers (30) were excluded from the counts.

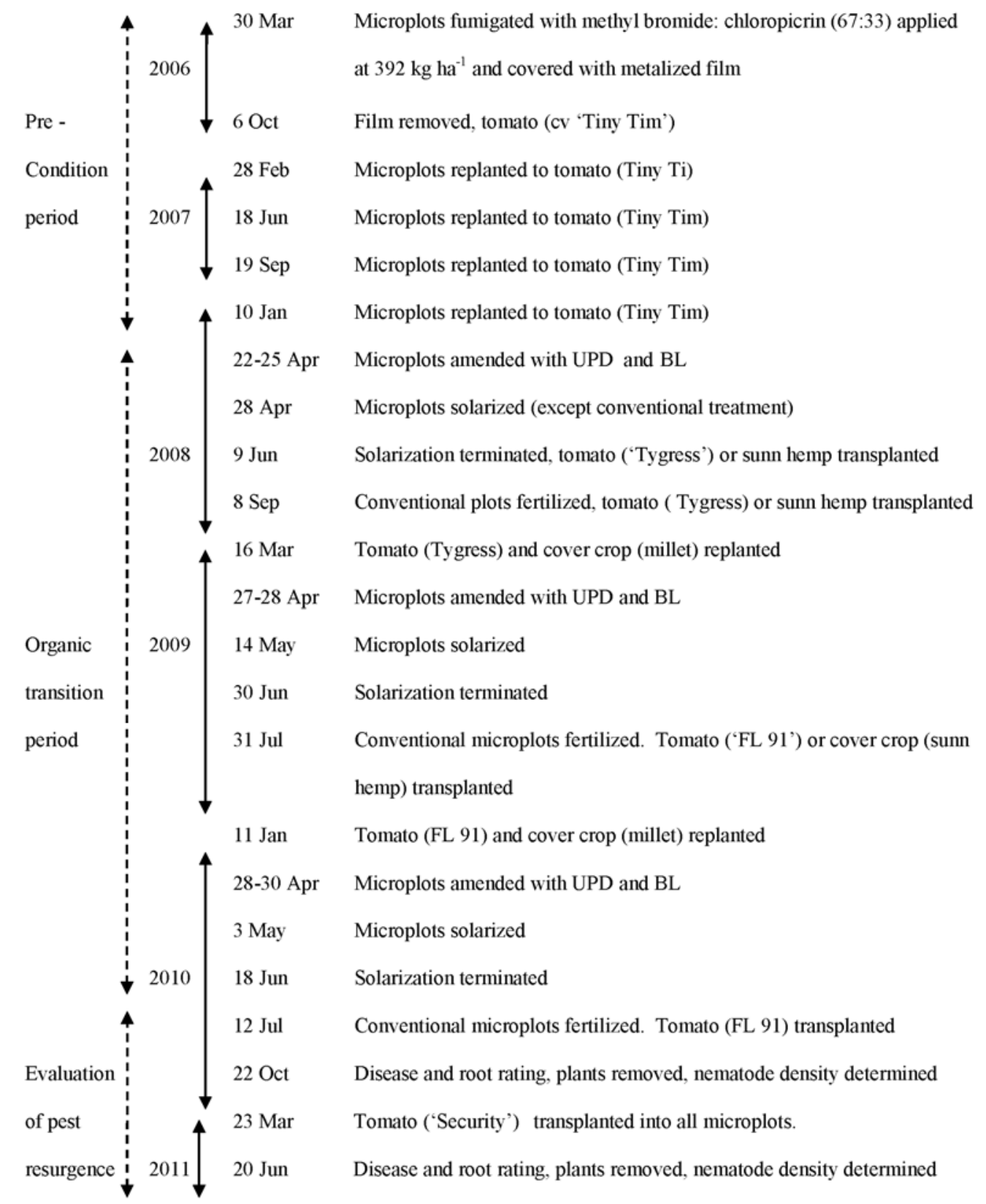

Fig. 1. Timeline of activities performed in microplots. UPD = urban plant debris and BL = broiler litter. Tomato cultivar Security was changed from 'Florida 91 ' in 2011 to provide resistance to Tomato yellow leaf curl virus. 
Viable tubers were assessed for visible galling caused by rootknot nematodes at the termination of the experiment.

Microplots were sampled at the end of the preconditioning period (March 2008), the end of the organic transition period (June 2010), and after the final tomato crop during the evaluation period for pest resurgence (June 2011) to determine soil pH, organic carbon, and total nitrogen. Four soil cores $(2.5$ by $12 \mathrm{~cm}$ ) were taken from each microplot and bulked together prior to analysis. Soil $\mathrm{pH}$ was determined using a 1:2 dilution of soil to water. Soil organic carbon and nitrogen were determined using a carbon/nitrogen soil analyzer (FLASH 1112 NC Analyzer; Thermo Fisher Scientific, Waltham, MA).

Data analysis. The effect of UPD, BL, and cropping sequence on disease incidence was analyzed using permutational analysis of variance (PERMANOVA). This statistical routine tests the simultaneous response of one or more variables to one or more factors in an analysis of variance (ANOVA) design using a resemblance measure (e.g., Bray-Curtis similarity coefficient). Hypothesis testing procedures rely upon permutation tests rather than traditional tables of the $F$ distribution to obtain a $P$ value (4). This method was chosen for analysis of disease incidence data because it makes no explicit assumption regarding the distribution of disease incidence data (i.e., assumptions of normality), relying instead upon a nonparametric rank-based approach with a hypothesis testing procedure using permutations to obtain $P$ values $(1,2)$. Pairwise Bray-Curtis similarity matrices (9) for the fall 2010 and spring 2011 tomato crops were constructed from disease incidence data using the nonparametric statistical package PRIMER 6 with the PERMANOVA+ add-on (PRIMER-E Ltd., Plymouth, UK) (3).

A distance based "pseudo- $F$ " statistic for each term in term in the model (UPD, BL, cropping sequence, UPD-BL, UPDcropping sequence, and BL-cropping sequence) was constructed based upon the expectations of mean squares, in a manner directly analogous to the construction of the $F$ statistic for multivariate models. Under the null hypothesis of no differences among groups, the pseudo- $F$ statistic from the actual data set is similar to values obtained under permutations obtained by randomly shuffling factors and the response variable (disease incidence). In this study, a minimum of 9,900 random permutations were run for each source in the model. Significant interactions between sources of variation were graphically depicted using hierarchical agglomerative clustering to provide a visual assessment of the level of association treatment combinations using nonparametric multivariate procedures outlined by Clarke (19) and Clarke and Warwick (20). Nematode and nutsedge data were statistically

TABLE 1. Soil amendment rates (expressed as $\mathrm{g} \mathrm{kg}^{-1}$ of soil)

\begin{tabular}{|c|c|c|c|c|c|}
\hline Amendment $^{\mathrm{a}}$ & Rate & Total N & $\mathrm{NH}_{3}$ & $\mathrm{P}$ & $\mathrm{K}$ \\
\hline \multicolumn{6}{|l|}{2008} \\
\hline Conventional fertilizer & $\ldots$ & 0.40 & 0.0 & 0.94 & 0.22 \\
\hline Broiler litter & 10 & 0.21 & 0.035 & 0.48 & 0.48 \\
\hline Urban plant debris & 30 & $<0.01$ & $<0.01$ & $<0.01$ & 0.01 \\
\hline Urban plant debris & 60 & $<0.01$ & $<0.01$ & $<0.01$ & 0.02 \\
\hline \multicolumn{6}{|l|}{2009} \\
\hline Conventional fertilizer & $\ldots$ & 0.20 & 0.0 & 0.047 & 0.11 \\
\hline Urban plant debris & 30 & $<0.01$ & $<0.01$ & $<0.01$ & $<0.01$ \\
\hline Urban plant debris & 60 & $<0.01$ & $<0.01$ & $<0.01$ & 0.01 \\
\hline \multicolumn{6}{|l|}{2010} \\
\hline Conventional fertilizer & $\ldots$ & 0.19 & 0.0 & 0.014 & 0.05 \\
\hline Broiler litter & 10 & 0.31 & 0.07 & 0.14 & 0.30 \\
\hline Broiler litter & 20 & 0.62 & 0.14 & 0.28 & 0.60 \\
\hline Urban plant debris & 30 & $<0.01$ & $<0.01$ & $<0.01$ & $<0.01$ \\
\hline
\end{tabular}

a Conventional fertilizer was applied only in the microplots that did not receive an application of broiler litter or urban plant debris.

TABLE 2. Soil temperatures during the soil solarization treatments

\begin{tabular}{|c|c|c|c|c|c|c|}
\hline \multirow[b]{2}{*}{ Parameters $^{\mathrm{a}}$} & \multicolumn{3}{|c|}{ Bare soil } & \multicolumn{3}{|c|}{ Clear plastic } \\
\hline & $5 \mathrm{~cm}$ & $10 \mathrm{~cm}$ & $25 \mathrm{~cm}$ & $5 \mathrm{~cm}$ & $10 \mathrm{~cm}$ & $25 \mathrm{~cm}$ \\
\hline \multicolumn{7}{|c|}{28 April to 12 June $2008 ; 1,075 \mathrm{~h}$} \\
\hline $\operatorname{Max}$ temp $\left({ }^{\circ} \mathrm{C}\right)$ & 41.21 & 39.55 & 38.45 & 48.87 & 47.22 & 44.75 \\
\hline $\mathrm{h}>40(n)$ & 5 & 0 & 0 & 101 & 105 & 39 \\
\hline $\mathrm{h}>40(\%)$ & 0.5 & 0 & 0 & 9.4 & 9.8 & 3.6 \\
\hline$h>45(n)$ & 0 & 0 & 0 & 20 & 4 & 0 \\
\hline $\mathrm{h}>45(\%)$ & 0 & 0 & 0 & 1.9 & 0.4 & 0 \\
\hline \multicolumn{7}{|c|}{14 May to 30 June $2009 ; 1,123 \mathrm{~h}$} \\
\hline $\operatorname{Max}$ temp $\left({ }^{\circ} \mathrm{C}\right)$ & 43.01 & 39.12 & 37.09 & 48.84 & 42.00 & 36.85 \\
\hline $\mathrm{h}>40(n)$ & 38 & 0 & 0 & 142 & 23 & 0 \\
\hline $\mathrm{h}>40(\%)$ & 3.4 & 0 & 0 & 12.6 & 2.0 & 0 \\
\hline $\mathrm{h}>45(n)$ & 0 & 0 & 0 & 41 & 0 & 0 \\
\hline $\mathrm{h}>45(\%)$ & 0 & 0 & 0 & 3.7 & 0 & 0 \\
\hline \multicolumn{7}{|c|}{3 May to 18 June $2010 ; 1,068 \mathrm{~h}$} \\
\hline $\operatorname{Max}$ temp $\left({ }^{\circ} \mathrm{C}\right)$ & 41.05 & 35.70 & 34.01 & 45.39 & 37.88 & 35.06 \\
\hline $\mathrm{h}>40(n)$ & 12 & 0 & 0 & 131 & 0 & 0 \\
\hline $\mathrm{h}>40(\%)$ & 1.1 & 0 & 0 & 12.3 & 0 & 0 \\
\hline $\mathrm{h}>45(n)$ & 0 & 0 & 0 & 1 & 0 & 0 \\
\hline $\mathrm{h}>45(\%)$ & 0 & 0 & 0 & 0.1 & 0 & 0 \\
\hline
\end{tabular}

a Max temp = maximum temperature; time shown in number of hours $(n)$ and percentage of hours.

b Between 12 and 15 June 2009, $61 \mathrm{~h}$ of data were missing due to lightning. 
analyzed according to standard ANOVA, and mean separation performed where appropriate using Fisher's protected least significant difference procedure (SAS Institute, Cary, NC). Unless otherwise stated, all differences referred to in the text were significant at the $5 \%$ level of probability.

\section{RESULTS}

Maximum soil temperature ranges achieved in the microplots during the soil solarization periods were lower than maximum temperatures previously recorded under clear plastic in Florida when solarization was conducted on raised beds $(12,17)$. The soil temperature ranges observed in this study were typical of solarization conducted on a flat surface (17) and were attributed to the microplot design. Soil temperatures during the 2010 solarization period exceeded $45^{\circ} \mathrm{C}$ for a single hour period at the 5-cm depth and were noticeably lower than temperatures observed in 2008 and 2009 (Table 2).

Effects on soilborne disease. The incidence of Fusarium wilt was $<1 \%$, despite attempts during the preconditioning period to inoculate soil with $F$. oxysporum f. sp. lycopersici. Thus, no data on the incidence of Fusarium wilt are presented. The mean incidence of bacterial wilt in the microplots was $21 \%$ in the fall 2010 planting and 29\% in the spring 2011 planting. Results from the PERMANOVA analysis are presented in Table 3. Cropping system significantly impacted bacterial wilt in the fall 2010 planting $(P=0.03)$ and disease incidence decreased from 33 to $9 \%$ when alternative cover crops were grown during the transitional period as compared with a continuation of tomato monoculture. Although less significant $(P=0.09)$, cropping system still affected the incidence of bacterial wilt in the 2011 planting, where disease incidence decreased from 40 to $18 \%$ when the alternative cover crops were grown during the transitional period. An interaction between cropping system and soil incorporation of UPD $(P=0.08)$ was observed in the 2010 planting. Treatments combining continued tomato monoculture with applications of UPD displayed a higher incidence of disease (40 to 53\%) compared with treatments that received no UPD or planted to cover crops during the transition period (Fig. 2). The interaction between cropping system and UPD during the spring 2011 planting was less evident $(P=0.19)$. However, the incidence of bacterial wilt remained greater in treatments combining a continued tomato monoculture with UPD (47 to $60 \%$ ) when compared with treat-

TABLE 3. Permutational analysis of variance of cropping system (CS), urban plant debris (UPD), and broiler litter (BL) effects on the incidence of bacterial wilt of tomato

\begin{tabular}{lcccc}
\hline Source $^{\mathrm{a}}$ & df & EMS $^{\mathrm{b}}$ & Pseudo- $F$ & $P($ perm $)$ \\
\hline Fall 2010 & & & & \\
CS & 1 & 8,379 & 6.10 & 0.03 \\
UPD & 2 & 3,918 & 2.85 & 0.08 \\
BL & 2 & 3,063 & 2.23 & 0.14 \\
CS $\times$ UPD & 2 & 4,007 & 2.91 & 0.08 \\
CS $\times$ BL & 2 & 3,301 & 2.40 & 0.09 \\
UPD $\times$ BL & 4 & 2,037 & 1.48 & 0.24 \\
Res & 4 & 1,373 & $\ldots$ & $\ldots$ \\
Spring 2011 & & & & \\
CS & 1 & 6,074 & 2.81 & 0.09 \\
UPD & 2 & 2,355 & 1.09 & 0.42 \\
BL & 2 & 2,572 & 1.19 & 0.37 \\
CS $\times$ UPD & 2 & 4,281 & 1.98 & 0.19 \\
CS $\times$ BL & 2 & 3,343 & 1.55 & 0.29 \\
UPD $\times$ BL & 4 & 3,410 & 1.58 & 0.19 \\
Res & 4 & 2,162 & $\ldots$ & $\ldots$ \\
\hline
\end{tabular}

${ }^{a}$ For both tomato plantings, $\mathrm{CS}=$ continued tomato monoculture versus alternative cover crops; UPD applied at 30 and $60 \mathrm{~g} \mathrm{~kg}^{-1}$ of soil at 0,12 , and 24 months; and BL applied at 10 and $20 \mathrm{~g} \mathrm{~kg}^{-1}$ of soil at 0,12 , and 24 months. Res $=$ residuals.

${ }^{\mathrm{b}}$ Expectations of mean square. ments not receiving UPD or planted with alternative cover crops during the transitional period (13 to $26 \%$ ). Hierarchical cluster analysis of the pairwise Bray-Curtis similarity matrices constructed from disease incidence ratings identified a high level of association ( $>75 \%$ similarity) among microplots receiving a high rate of UPD (60 $\mathrm{g} \mathrm{kg}^{-1}$ of soil) under continuous tomato monoculture (Fig. 3) in regards to the incidence of bacterial wilt. This was evident for both the fall 2010 and spring 2011 growing season. By contrast, combinations of cropping sequence and UPD in the cluster analysis that shared $100 \%$ similarity were characterized as having no bacterial wilt. Eight combinations with no disease were detected in the fall 2010 growing season and five combinations in the spring 2011 season and included one group of microplots receiving the high application rate of UPD but subjected to alternative cover crops during the 2-year transitional period.

Effect on purple nutsedge populations. Purple nutsedge populations increased from 4 tubers planted into each microplot to $>400$ tubers per plot during the 2-year preconditioning period. The number of tubers produced per plot dropped each year following the transition period, although there were no significant treatment effects until the final nutsedge tuber harvest. At that time, only the addition of BL significantly impacted purple nutsedge populations. Although the percent surface area covered by nutsedge shoots did not differ among manure rates, the number of viable nutsedge tubers produced per microplot significantly increased with both BL application rates (Fig. 4). No significant interactions among UPD, BL, and cropping sequence were observed with respect to purple nutsedge populations. At the conclusion of the experiment, $100 \%$ of the plots had nutsedge tubers that were visibly infected with root-knot nematodes.

Effects on nematode populations in soil and root galling caused by $M$. incognita. Cropping sequence and organic amend-

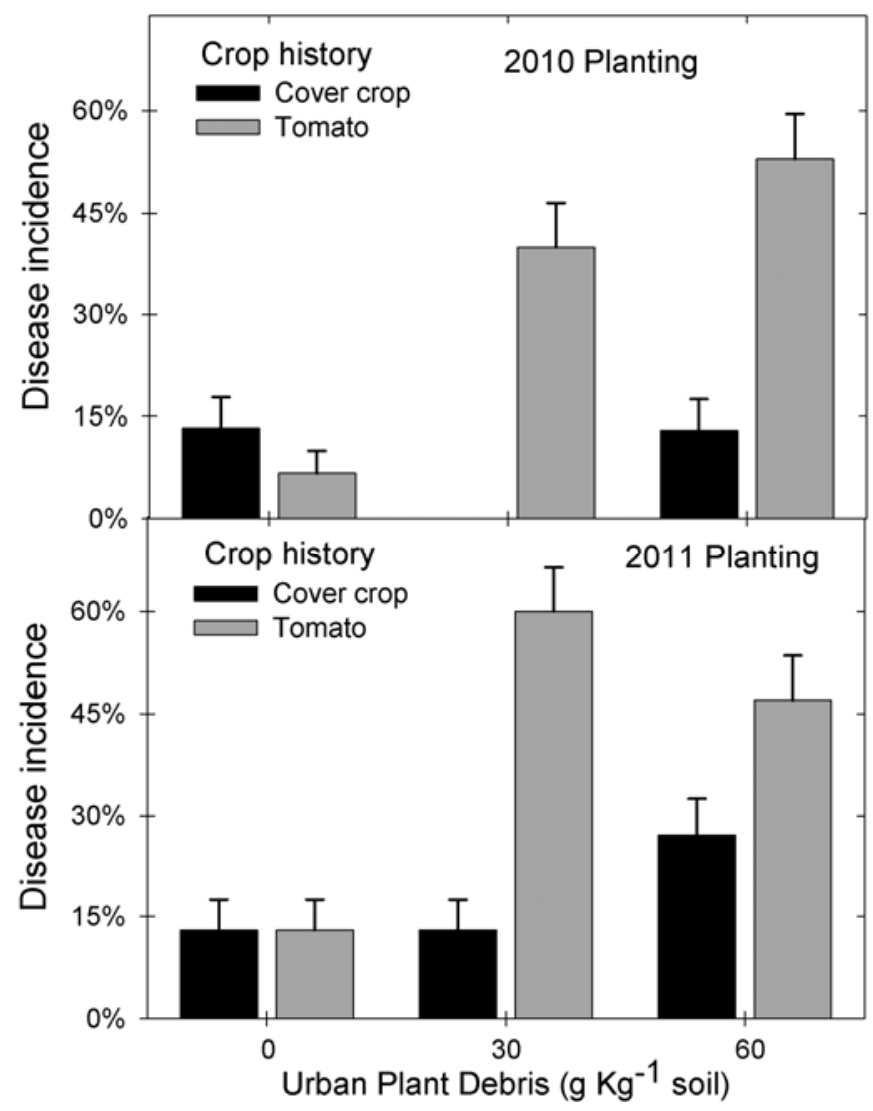

Fig. 2. Interactive effects of cropping sequence and soil incorporation of urban plant debris on the incidence of bacterial wilt of tomato. Error bars represent the standard error. 
ments (BL and UPD) did not significantly impact the soil density of root-knot nematodes at the conclusion of the fall 2010 and spring 2011 plantings. No interactions were observed between BL and UPD on the soil density of root-knot nematode juveniles. Significant treatment effects on soil populations of other parasitic or nonparasitic nematodes were not observed, except after the fall 2010 planting, where significantly higher populations of nonparasitic nematodes were observed in plots amended with BL (26 to 32 nematodes $100 \mathrm{~cm}^{-3}$ of soil) as compared with plots not receiving $\mathrm{BL}$ (15 nematodes $100 \mathrm{~cm}^{-3}$ of soil). BL applications did not affect soil populations of nonparasitic nematodes after the spring 2011 crop. Damage to tomato root systems by M. incognita, measured by the severity of root galling, was significantly impacted by the interaction of cropping sequence and BL soil amendment. After the fall 2010 crop, the severity of root galling was significantly higher in plots subjected to continued tomato monoculture and annual applications of BL (Fig. 5). After the spring 2011 crop, root gall ratings in microplots receiving BL at $10 \mathrm{~g} \mathrm{~kg}^{-1}$ of soil were higher when a tomato monoculture was continued as compared with plots where an alternative crop rotation was employed.

Soil $\mathrm{pH}$, organic carbon, and total nitrogen were examined with respect to the significant interactions affecting bacterial wilt (cropping sequence-UPD) and root galling (cropping sequence$\mathrm{BL}$ ). Soil $\mathrm{pH}$ was not affected during the three soil sample periods (Table 4) and, thus, did not appear to influence the incidence of bacterial wilt of tomato. Soil organic carbon and soil nitrogen increased with increasing application of UPD during the organic
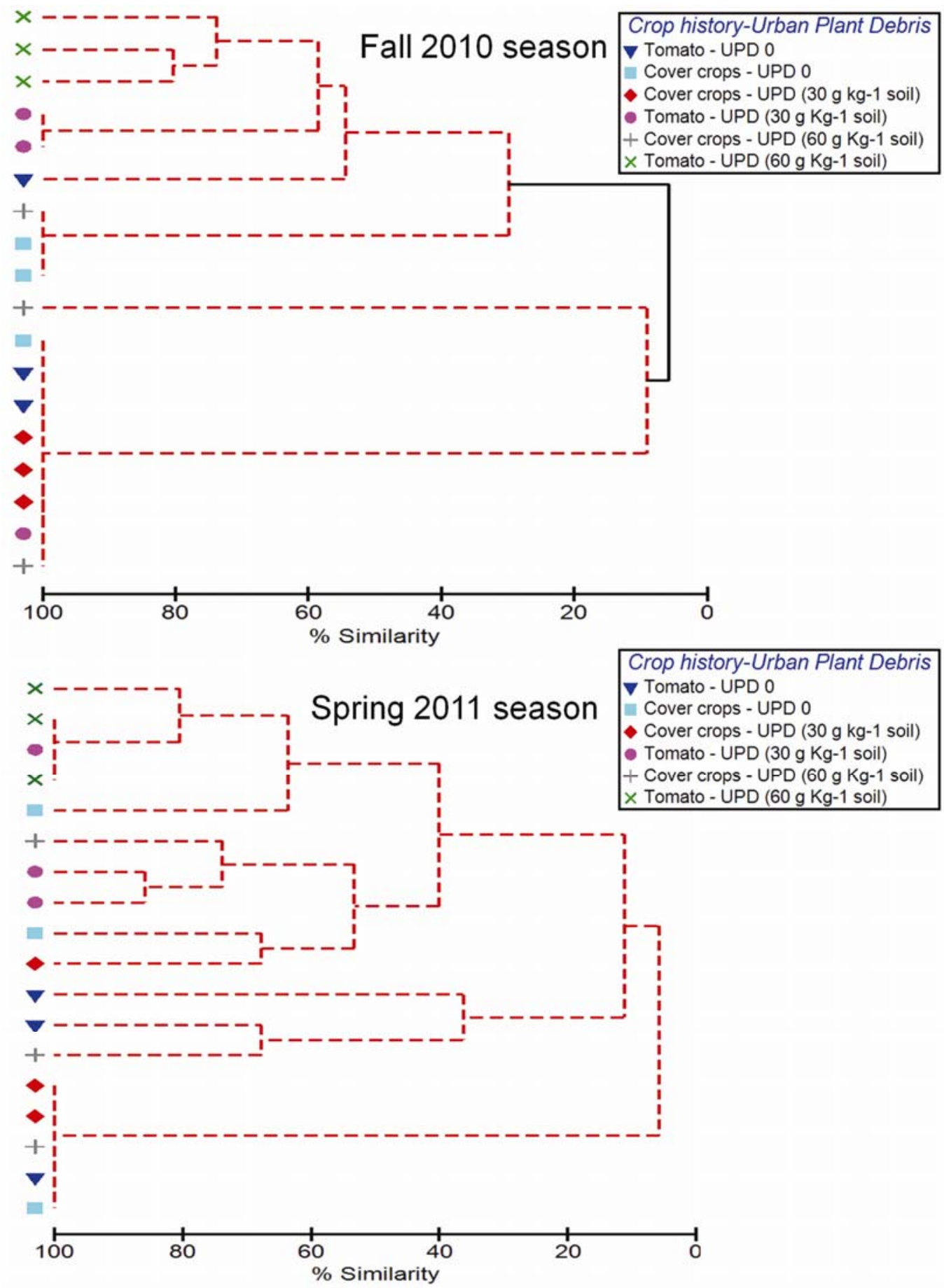

Fig. 3. Dendrograms depicting the degree of association among microplots with respect to the incidence of bacterial wilt of tomato based upon the results from hierarchical cluster analysis of pairwise Bray-Curtis similarity matrices constructed from disease incidence ratings. 

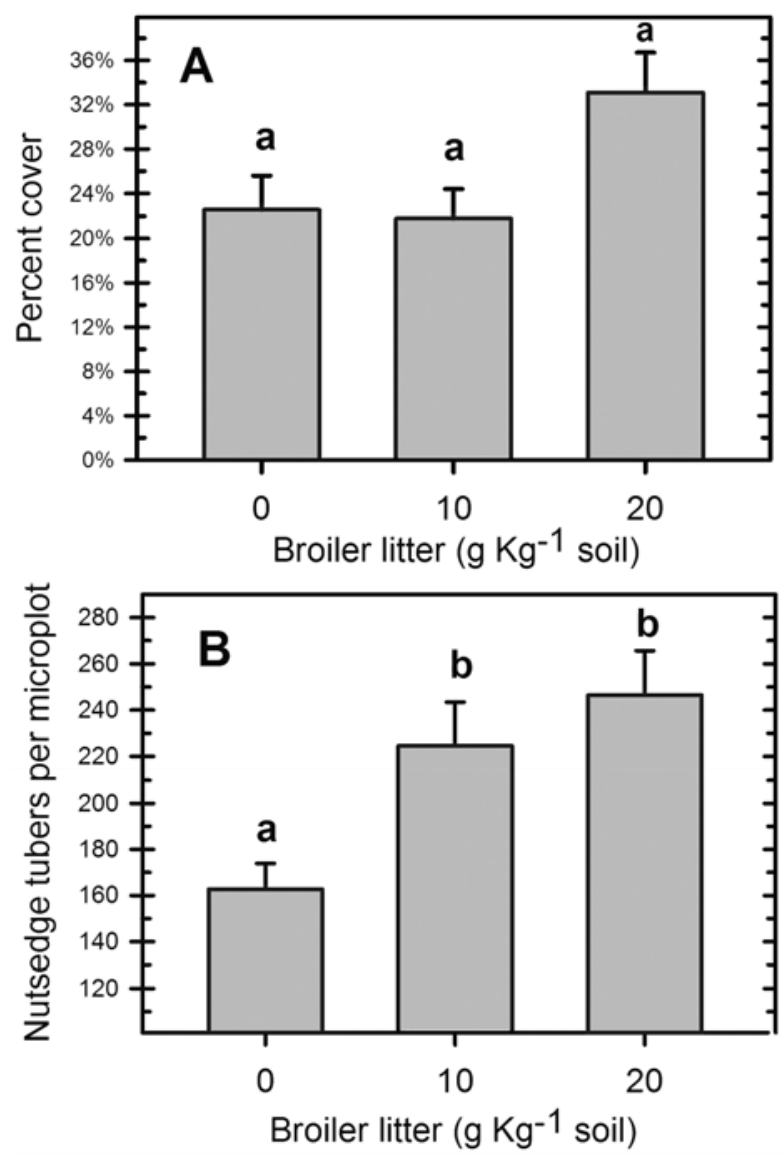

Fig. 4. Effect of broiler litter applied over a 2-year organic transitional period on $\mathbf{A}$, the percent cover and $\mathbf{B}$, the number of nutsedge tubers per microplot. Error bars represent the standard error. Means followed by the same letter do not differ according to least significant difference $(P \leq 0.05)$.

transition period and remained elevated during the evaluation period for pest resurgence.

\section{DISCUSSION}

Although the soil solarization component of the system employed in this study was expected to significantly impact purple nutsedge shoot emergence, the percentage of the plots covered with nutsedge shoots was equivalent across all manure treatments. Interestingly, the greatest number of tubers was produced in the plots with manure versus those that were solarized with inorganic $\mathrm{N}$ applications. Solarization and solarization combined with organic amendments have been reported as effective means of both purple and yellow nutsedge management $(12,13$, 17) but the full impact of this approach is only realized when solarization results in thermal times that are effective for the target organism. Webster (57) reported that $71 \mathrm{~h}$ at $45^{\circ} \mathrm{C}$ is required to reduce purple nutsedge tuber viability by $50 \%$ and a 24-h exposure at $50^{\circ} \mathrm{C}$ was required to reduce new purple nutsedge tuber production by $50 \%$. In this study, thermal accumulation during the solarization periods of 2008, 2009, and 2010 did not reach thresholds high enough to effectively control purple nutsedge and no enhancement of control was observed when BL or UPD was added to the plots prior to initiation of the solarization period. The cover crop regime imposed during the 2-year transition period also failed to impact purple nutsedge tuber production in this study. Lack of control may be due to the physical limitation of the microplot system with regard to establishing a dense sunn hemp canopy to effectively reduce photosynthetically active radiation from reaching the soil surface. The

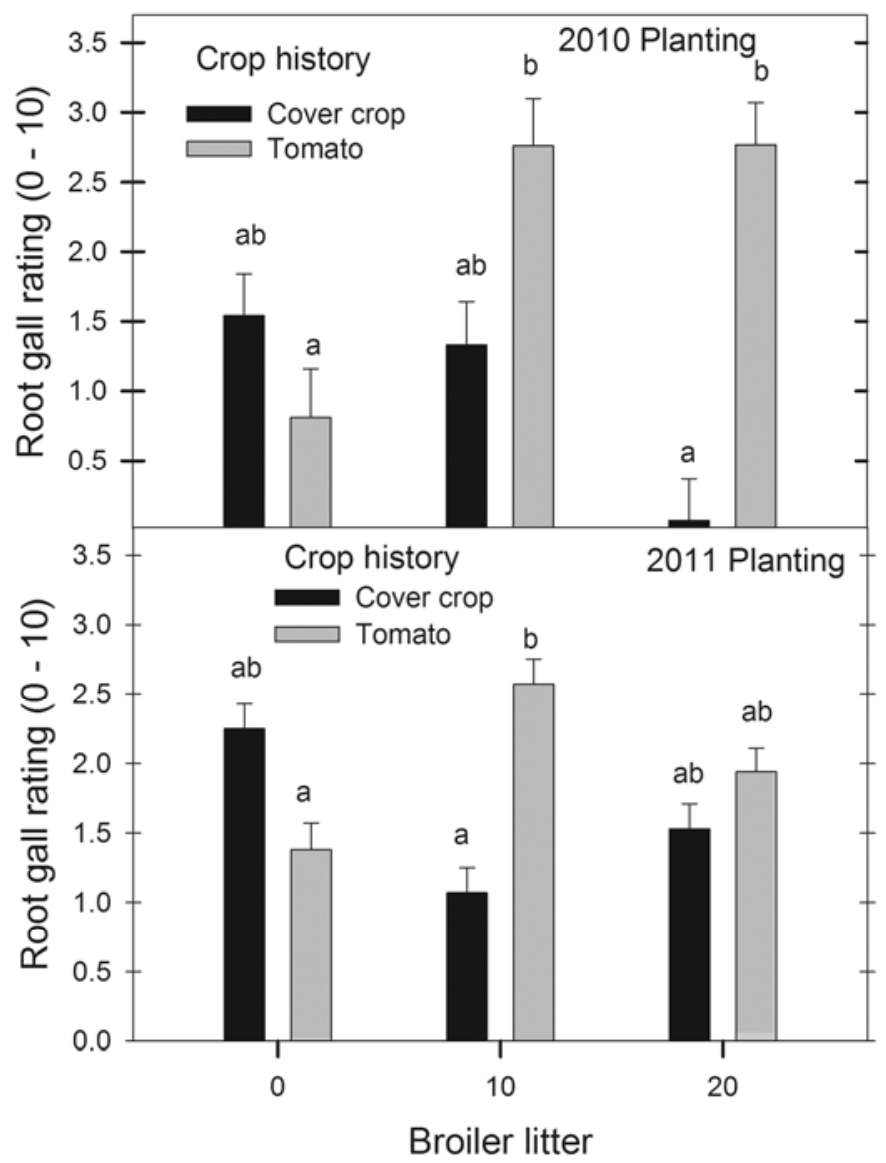

Fig. 5. Interactive effects of cropping sequence and soil incorporation of broiler litter on the severity of root galling by Meloidogyne incognita. Error bars represent the standard error. Means followed by the same letter do not differ according to least significant difference $(P \leq 0.05)$.

selection of a cover crop which more effectively shades the emerging shoots could significantly enhance the control of nutsedge (49). The significant increase in nutsedge tubers following incorporation of BL is attributed to additional nitrogen levels in BL-amended plots, which resulted in greater early production of basal bulbs and shoots (49), with a shift to tuber production as the nitrogen became limiting.

Our data support the view that crop rotation during the transitional period from conventional to organic agriculture is vital to mitigate the risk of soilborne disease and plant-parasitic nematode resurgence. From an ecological perspective, biodiversity is believed to play a major role in the stability and reliability of ecosystems $(31,39,52)$, particularly the relationship between plant species richness and outbreaks of plant disease (34). From an applied perspective, multiple studies indicate that increasing plant diversity through crop rotation can reduce the incidence and severity of soilborne disease $(46,47)$ and can reduce the impact of plant-parasitic nematodes in field agronomic systems $(38,43$, $44,55)$. In this study, a reduction in bacterial wilt occurred under the alternative sunn hemp/millet cropping sequence when compared with continuous tomato monoculture. In a previous study examining the effects of organic transition strategies, damping-off of tomato under a mixed-hay transitional cropping sequence was reduced when compared with damping-off following intensive vegetable production (6). Root galling as a result of $M$. incognita was also reduced in the sunn hemp/millet rotation. This is particularly relevant because root-knot nematode populations in soil and roots have been reported to rebound quickly and reestablish in large numbers following soil fumigation in Florida agricultural soils, which are conducive to nematode reproduction 
TABLE 4. Soil pH, organic carbon (C), and total nitrogen (N) at the end of the preconditioning period (March 2008), organic transition period (June 2010), and evaluation of pest resurgence (June 2011)

\begin{tabular}{|c|c|c|c|c|c|c|c|c|c|c|}
\hline \multirow[b]{2}{*}{ Treatment $^{\mathrm{a}}$} & \multirow[b]{2}{*}{ Crop } & \multicolumn{3}{|c|}{ Soil pH } & \multicolumn{3}{|c|}{ Organic carbon $\left(\mathrm{kg} \mathrm{ha}^{-1}\right)$} & \multicolumn{3}{|c|}{ Total N $\left(\mathrm{kg} \mathrm{ha}^{-1}\right)$} \\
\hline & & March $2008^{b}$ & June 2010 & June 2011 & March 2008 & June 2010 & June 2011 & March 2008 & June 2010 & June 2011 \\
\hline \multicolumn{11}{|l|}{ UPD } \\
\hline 0 & Tomato & 6.3 & 6.8 & 7.4 & 17,400 & 13,594 & 12,528 & 544 & 1,066 & 566 \\
\hline 30 & Tomato & 6.3 & 6.8 & 7.4 & 17,400 & 24,578 & 14,660 & 544 & 1,674 & 783 \\
\hline 30 & Cover & 6.3 & 6.7 & 7.3 & 17,400 & 24,143 & 21,380 & 544 & 1,761 & 1,109 \\
\hline 60 & Tomato & 6.3 & 6.8 & 7.3 & 17,400 & 31,103 & 28,058 & 544 & 1,914 & 1,196 \\
\hline 0 & Tomato & 6.3 & 6.8 & 7.4 & 17,400 & 20,206 & 13,628 & 544 & 1,109 & 478 \\
\hline 0 & Cover & 6.3 & 6.7 & 7.3 & 17,400 & 20,010 & 16,922 & 544 & 1,131 & 674 \\
\hline 10 & Tomato & 6.3 & 6.8 & 7.4 & 17,400 & 24,630 & 20,119 & 544 & 1,566 & 1,065 \\
\hline 10 & Cover & 6.3 & 6.8 & 7.2 & 17,400 & 21,446 & 18,031 & 544 & 1,653 & 826 \\
\hline 20 & Tomato & 6.3 & 6.7 & 7.3 & 17,400 & 24,795 & 21,685 & 544 & 1,979 & 1,000 \\
\hline 20 & Cover & 6.3 & 6.8 & 7.3 & 17,400 & 25,013 & 17,400 & 544 & 2,044 & 1,065 \\
\hline
\end{tabular}

${ }^{\mathrm{a}} \mathrm{UPD}=$ urban plant debris applied at 0,30 , and $60 \mathrm{~g} \mathrm{~kg}^{-1}$ of soil and $\mathrm{BL}=$ broiler liter applied at 0,10 , and $20 \mathrm{~g} \mathrm{~kg}^{-1}$ of soil.

b All microplots received the identical treatment during the preconditioning period; hence, similar values for soil pH, organic $\mathrm{C}$, and total $\mathrm{N}$.

(35). It should be noted that many growers transitioning from conventional to organic production would prefer to continue with a monoculture of their primary cash crop in lieu of alternative cover crops to ensure a continuation of revenue generated from crop production.

Soil incorporation of organic amendments can reduce the incidence of soilborne disease $(36,50)$. However, disease suppression from organic soil amendments is often variable. Termorshuizen et al. (51) compared the effectiveness of 18 different composts on seven pathosystems and concluded that no single compost showed significant disease suppression against all pathogens. Variability in effectiveness of soil amendments is further compounded in the field, where effects are generally more variable than those in container experiments $(40,45)$. This study split the organic soil amendment applications into their respective sources: UPD and BL. Each source differs greatly in their nutrient contribution to soil fertility (Table 1) and their biological and chemical contributions to the soil environment (D. Chellemi, unpublished data). Differential interactions were observed between the transitional cropping system employed and the source/composition of organic soil amendment in regards to the incidence of bacterial wilt of tomato. Although amending soil with UPD was shown to reduce Phytophthora blight and Pythium root rot of bell pepper in a previous study (14), amending microplots with UPD led to significantly higher incidences of bacterial wilt in this study in microplots where tomato was continuously planted. The UPD used in this study was not finished compost and was not stabilized when added to the microplots. Fresh, undecomposed organic matter does not support biocontrol, even when inoculated with biological control agents (23). One explanation for the increase in disease increase is that UPD-amended soil provided additional carbon sources and colonization sites for $R$. solanacearum populations that were simultaneously being enhanced by continuous tomato monoculture in soil naturally infested with $R$. solanacearum. In disease-conducive soil, $R$. solanacearum is capable of exclusively utilizing several carbon sources that associated rhizobacterial communities cannot (33), and it is postulated that the lack of competition between the pathogen and rhizobacteria for carbon sources played an important role in the increase in disease. Another scenario that may have contributed to increased bacterial wilt in UPD-amended soil is competition among soil microbes for iron. Iron availability is critical for survival and function of bacteria and, because iron forms complexes with organic carbon, particularly dissolved organic carbon, its biological availability can be reduced in soils with elevated dissolved carbon. The production of siderophores, biosynthetic chelates that enhance the ability of bacteria to acquire iron from the soil, may have provided $R$. solanacearum a competitive edge for survival and growth in UPD-amended soil $(7,22)$. In a previous study, fully composted UPD did not significantly impact the incidence of bacterial wilt of tomato in two different soil types (16). Thus, it is postulated that use of fully composted UPD would not have increased suppression of bacterial wilt in this study. Increasing soil carbon through addition of green manure also increased the incidence of bacterial wilt in an additional previous study (59).

Differential interactions were observed between the transitional cropping system employed and the source or composition of organic soil amendment with regard to root galling by $M$. incognita. In previous field studies, applications of BL up to $22 \mathrm{Mg}$ $\mathrm{ha}^{-1}$ reduced populations of plant-parasitic nematodes $(14,42)$ as well as incorporation of composted organic amendments $(36,50)$. In this study, BL increased the severity of root galling in the presence of a continued tomato monoculture. These results illustrate the difficulty in predicting the outcome of soil amendments on disease incidence while transitioning to organic production. Each component of the system had differential impacts on each measured parameter, making it difficult to establish broad generalizations about the role that inputs play in this system. A similar phenomenon was observed in recent studies employing anaerobic soil disinfestations in which soil solarization was combined with BL, molasses, and soil saturation. The fungal plant pathogen $F$. oxysporum $\mathrm{f}$. sp. lycopersici race 3 was most effectively controlled by treatments containing molasses as an input, whereas root-knot nematode control was highly dependent upon soil saturation (11). The results illustrate the importance of a systems-based approach to implementing transitional organic practices that is cognizant of their interactive effects on resident soil disease and pest complexes. However, as previously noted by Collange et al. (21), many alternative soilborne pest management practices are only partially effective, creating an added challenge for combining practices in a systematic way.

\section{ACKNOWLEDGMENTS}

We thank N. Rotindo, K. Rotindo, A. Rhinehart, M. Bobb, and T. Ivy for technical support. Mention of a trademark, warranty, proprietary product, or vendor does not constitute a guarantee by the United States Department of Agriculture and does not imply its approval to the exclusion of other products or vendors that may also be suitable.

\section{LITERATURE CITED}

1. Anderson, M. J. 2001. A new method for non-parametric multivariate analysis of variance. Aust. Ecol. 26:32-46. 
2. Anderson, M. J. 2001. Permutation tests for univariate or multivariate analysis of variance and regression. Can. J. Fish. Aquat. Sci. 58:626-639.

3. Anderson, M. J., Gorley, R. N., and Clarke, K. R. 2008. PERMANOVA+ for PRIMER: Guide to Software and Statistical Methods. PRIMER-E Ltd., Plymouth, UK.

4. Anderson, M. J., and ter Braak, C. J. F. 2003. Permutation tests for multifactorial analysis of variance. J. Stat. Comput. Simul. 73:85-113.

5. Bao, J. R., Fravel, D. R., O’Neill, N R., Lazarovits, G., and van Berkum, P. 2002. Genetic analysis of pathogenic and nonpathogenic Fusarium oxysporum from tomato plants. Can J. Bot. 80:271-279.

6. Baysal, F., Benitez, M. S., Kleinhenz, M. D., Miller, S. A., and McSpadden Gardener, B. B. 2008. Field management effects on damping-off and early season vigor of crops in a transitional organic cropping system. Phytopathology 98:562-570.

7. Bhatt, G., and Denny, T. P. 2004. Ralstonia solanacearum iron scavenging by the siderophore staphyloferrin B is controlled by PhcA, the global virulence regulator. J. Bacteriol. 186:7896-7904.

8. Bononomi, G., Antignani, V., Pane, C., and Scala, F. 2007. Suppression of soilborne fungal diseases with organic amendments. J. Plant Pathol. 89: 311-324.

9. Bray, J. R., and Curtis, J. T. 1957. An ordination of the upland forest communities of Southern Wisconsin. Ecol. Monogr. 27:325-349.

10. Bridge, J., and Page, S. L. J. 1980. Estimation of root-knot infestation levels in roots using a rating chart. Trop. Pest. Manage. 26:296-298.

11. Butler, D., Kokalis-Burelle, N., Muramoto, J., Shennan, C., McCollum, T. G., and Rosskopf, E. N. 2012. Impact of anaerobic soil disinfestations combined with soil solarization on plant-parasitic nematodes and introduced inoculums of soilborne plant pathogens in raised-bed vegetable production. Crop. Prot. 39:33-40.

12. Chase, C. A., Sinclair, T. R., and Locascio, S. J. 1999. Effects of soil temperature and tuber depth on Cyperus spp. control. Weed Sci. 47:467472.

13. Chase, C. A., Sinclair, T. R., Chellemi, D. O., Olson, S. M., Gilreath, J. P., and Locascio, S. J. 1999. Heat-retentive films for increasing soil temperatures during solarization in a humid, cloudy environment. HortScience 34:1085-1089.

14. Chellemi, D. O. 2006. Effect of urban plant debris and soil management practices on plant parasitic nematodes, Phytophthora blight and Pythium root rot of bell pepper. Crop Prot. 25:1109-1116.

15. Chellemi, D. O., Mirusso, J., Nance, J., and Shuler, K. 2001. Results from field scale demonstrations/validation studies of Telone products on the Florida east coast. Florida Tomato Inst. Proc. Citrus Veg. Mag. March:5158 .

16. Chellemi, D. O., Mitchell, D. J., and Barkdol, A. W. 1992. Effect of composted organic amendments on the incidence of bacterial wilt of tomato. Proc. Fla. State Hortic. Soc. 105:364-366.

17. Chellemi, D. O., Olson, S. M., Mitchell, D. J., Secker, I., and McSorley, R. 1997. Adaptation of soil solarization to the integrated management of soilborne pests of tomato under humid conditions. Phytopathology $87: 250-258$.

18. Chellemi, D. O., Wu, Tiehang, Graham, J. H., and Church, G. 2012. Biological impact of divergent land management practices on tomato crop health. Phytopathology 102:597-608.

19. Clarke, K. R. 1993. Non-parametric multivariate analyses of changes in community structure. Aust. J. Ecol. 18:117-143.

20. Clarke, K. R., and Warwick, R. M. 2001. Change in Marine Communities: An Approach to Statistical Analysis and Interpretation, 2nd ed. Primer-E, Plymouth, UK

21. Collange, B., Navarrete, M., Peyre, G., Mateille, T., and Tchamitchian. 2011. Root-knot nematode (Meloidogyne) management in vegetable crop production: The challenge of an agronomic system analysis. Crop. Prot. 30:1251-1262.

22. Crowley, D. E., Wang, Y. C., Reid, C. P. P., and Szaniszlo, P. J. 1991. Mechanisms of iron acquisition from siderophores by microorganisms and plants. Plant Soil 130:179-198.

23. De Ceuster, T. J. J., and Hoitink, A. J. 1999. Prospects for composts and biocontrol agents as substitutes for methyl bromide in biological control of plant diseases. Compost Sci. Util. 1:7-15.

24. Dimitri, C., and Oberholtzer, L. 2009. Marketing U.S. organic foods: Recent trends from farms to consumers. U.S. Dep. Agric. ERS Econ. Inf. Bull. 58.

25. Federal Register. 1993. Fed. Registr. 58:65018-65082.

26. Geraldson, C. M., Overman, A. J., and Jones, J. P. 1965. Combination of high analysis fertilizers, plastic mulch and fumigation for tomato production on old agricultural land. Soil Crop Soc. Fla. Proc. 25:18-24.

27. Gilbert, R. A., Rice, R. W., and Lentini, R. S. 2008. Characterization of selected mineral soils used for sugarcane production. Univ. Fla. IFAS Ext. Publ. SS-AGR-227.

28. Gilreath, J. P., Motis, T. N., Bielinski, M. S., Noling, J. W., Locascio, S. J., and Chellemi, D. O. 2005. Resurgence of soilborne pests in double- cropped cucumber after application of methyl bromide chemical alternatives and solarization in tomato. HortTechnology 15:1-5.

29. Gilreath, J. P., Noling, J. W., Gilreath, P. R., and Jones, J. P. 1997. Field validation of 1,3-dichloropropene + chloropicrin and pebulate as an alternative to methyl bromide in tomato. Proc. Fla. State Hortic. Soc. 110:273276.

30. Grichar, W. J. 2002. Effect of continuous imidazolinone herbicide use on yellow nutsedge (Cyperus esculentus) populations in peanut. Weed Technol. 16:880-884.

31. Hughes, A. R., and Stachowicz, J. J. 2004. Genetic diversity enhances the resistance of a seagrass ecosystem to disturbance. Proc. Natl. Acad. Sci. USA 101898-9002.

32. Hussey, R. S., and Barker, K. R. 1973. A comparison of methods of collecting inocula for Meloidogyne spp., including a new technique. Plant Dis. Rep. 57:1025-1028.

33. Irikin Y., Nishiyama, M., Otsuka, S., and Senoo, K. 2006. Rhizobacterial community-level, sole carbon source utilization pattern affects the delay in the bacterial wilt of tomato grown in rhizobacterial community model system. Appl. Soil Ecol. 34:27-32.

34. Knops, J. M. H., Tilman, D., Haddad, N. M., Naeem, S., Mitchell, C. E., Haarstad, J., Ritchie, M. E., How, K. M., Reich, P. B., Siemann, E., and Groth, J. 1999. Effects of plant species richness on invasion dynamics, disease outbreaks, insect abundances and diversity. Ecol. Lett. 2:286-293.

35. Kokalis-Burelle, N., Rosskopf, E. N., Albano, J. P., and Holzinger, J. 2010. Effects of Midas on nematodes in commercial floriculture production in Florida. J. Nematol. 42:17-21.

36. Lewis, J. A., Lumsden, R. D., Milner, P. D., and Keinath, A. P. 1992 Suppression of damping-off of peas and cotton in the field with composted sewage sludge. Crop Prot. 11:260-266.

37. Locascio, S. J., Gilreath, J. P. Dickson, D. W., Kucharek, T. A., Jones, J. P., and Noling, J. W. 1997. Fumigant alternatives to methyl bromide for polyethylene mulched tomato. HortScience 32:1208-1211.

38. McSorley, R., Dickson, D. E., de Brito, J. A., and Hochmuth, R. C. 1994. Tropical rotation crops influence nematode densities and vegetable yields. J. Nematol. 26:308-314.

39. Naeem, S., and Li, S. 1997. Biodiversity enhances ecosystem reliability. Nature 390:507-509.

40. Noble, R., and Coventry, E. 2005. Suppression of soil-borne plant diseases with composts: A review. Biocontrol Sci. Technol. 15:3-20.

41. Obreza, T. A., and Collins, M. E. 2002. Commons soils used for citrus production in Florida. Univ. Fla. IFAS Ext. Publ. SL 193.

42. Riegel, C., and Noe, J. P. 2000. Chicken litter soil amendment effects on soilborne microbes and Meloidogyne incognita on cotton. Plant Dis. $84: 1275-1281$

43. Rodriguez-Kabana, R., King, P. S., Robertson, D. G., and Weaver, C. F. 1988. Potential of crops uncommon to Alabama for management of rootknot and soybean cyst nematodes. Ann. Appl. Nematol. 2:116-120.

44. Rodriguez-Kabana, R., Robertson, D. G., Weaver C. F., and Wells, L. 1991. Rotations of bahiagrass and castorbean with peanut for the management of Meloidogyne arenaria. J. Nematol. (Suppl.) 23:658-661.

45. Scheuerell, S. J., Sullivan, D. M., and Mahaffee, W. F. 2005. Suppression of seedling damping-off caused by Pythium ultimum, P. irregulare, and Rhizoctonia solani in container media amended with a diverse range of Pacific Northwest compost sources. Phytopathology 95:306-315.

46. Schutter, M. E., and Dick, R. P. 2002. Microbial community profiles and activities among aggregates of winter fallow and cover-cropped soil. Soil Sci. Soc. Am. J. 66:142-153.

47. Seigies, A. T., and Pritts, M. 2006. Cover crop rotations alter soil microbiology and reduce replant disorders in strawberry. HortScience 41:1303-1308.

48. Spreen, T. H., VanSickle, J. J., Moseley, A. E., Deepak, M. S., and Mathers, L. 1995. Use of methyl bromide and the economic impact of its proposed ban on the Florida fruit and vegetable industry. Univ. Fla. Inst. Food Agric. Sci. Bull. 898 (Tech.)

49. Stoller, E. W., and Sweet, R. D. 1987. Biology and life cycle of purple and yellow nutsedges (Cyperus rotundus and $C$. esculentus). Weed Technol. 1:66-73.

50. Stone, A. G., Vallad, G. E., Cooperband, L. R., Rotenberg, D., Darby, H. R., James, R. V., Stevenson, W .R., and Goodman, R .M. 2003. Effect of organic amendments on soilborne and foliar diseases in field-grown snap bean and cucumber. Plant Dis. 87:1037-1042.

51. Termorshuizen, A. J., van Rijn, E., van der Gaag, D. J., Alabouvette, C., Chen, Y., Lagerlof, J., Malandrakis, A. A., Paplomatas, E. J., Ramer, B., and Ryckeboer, J. 2006. Suppressiveness of 18 composts against 7 pathosystems: Variability in pathogen response. Soil Biol. Biochem. 38:24612477.

52. Tilman, D. 1996. Biodiversity population versus ecosystem stability. Ecology $77: 350-363$.

53. USEPA. 2006. 2006 Critical Use Exemption Nominations from the Phaseout of Methyl Bromide. http://www.epa.gov/ozone/mbr/2006_nomination.htm 
54. van Bruggen, H. C. 1995. Plant disease severity in high-input compared to reduced-input and organic farming systems. Plant Dis. 79:976-984.

55. Wang, K. H., McSorley, R., and Kokalis-Burelle, N. 2006. Effects of cover cropping, solarization, and soil fumigation on nematode communities. Plant Soil 286:229-243.

56. Watts, F. C., and Stankey, D. L. 1980. Soil Survey of St. Lucie County Area, Florida. USDA, Soil Conservation Service; University of Florida, Institute of Food and Agricultural Sciences; and Florida Department of Agriculture and Consumer Services.
57. Webster, T. M. 2003. High temperatures and durations of exposure reduce nutsedge (Cyperus spp.) tuber viability. Weed Sci. 51:1010-1015.

58. Winsberg, T., Chellemi, D. O., Mellinger, M., and Shuler, K. D. 1998. Transition to a biorational farm management system using soil solarization in a commercial pepper operation. Proc. Fla. State Hortic. Soc. 111:78-79.

59. Yadessa, G. B., van Bruggen, A. H. C., and Ocho, F. L. 2010. Effects of different soil amendments on bacterial wilt caused by Ralstonia solanacearum and on the yield of tomato. J. Plant Pathol. 92:439-450. 